\title{
Trophic ecology of the European hake in the Gulf of Lions, northwestern Mediterranean Sea
}

\author{
Capucine Mellon-Duval ${ }^{1}$, Mireille Harmelin-Vivien ${ }^{2}$, Luisa Métral ${ }^{1}$, Véronique Loizeau ${ }^{3}$, \\ Serge Mortreux ${ }^{1}$, David Roos ${ }^{4}$, Jean-Marc Fromentin ${ }^{1}$ \\ ${ }^{1}$ Ifremer, UMR MARBEC, Station Ifremer de Sète, Avenue Jean Monnet, CS 30171, 34203 Sète Cedex, France. \\ (CM-D) (Corresponding author) E-mail: cmellon@ifremer.fr. ORCID iD: http://orcid.org/0000-0002-2811-1779 \\ (LM) E-mail: Luisa.Metral@ifremer.fr. ORCID iD: http://orcid.org/0000-0002-8187-0053 \\ (SM) E-mail: Serge.Mortreux@ ifremer.fr. ORCID iD: http://orcid.org/0000-0002-446-2592 \\ (JMF) E-mail: Jean.Marc.Fromentin@ifremer.fr. ORCID iD: http://orcid.org/0000-0002-1496-4332 \\ ${ }^{2}$ Université d'Aix Marseille, Mediterranean Institute of Oceanography (MIO), UM 110, 13288 Marseille Cedex 09, France. \\ (MH) E-mail: mireille.harmelin@mio.osupytheas.fr. ORCID iD: http://orcid.org/0000-0003-3085-2899 \\ ${ }^{3}$ Ifremer, Laboratoire Biogéochimie des Contaminants Organiques, ZI de la Pointe du Diable, CS 10070, 29280 Plouzané, \\ France. \\ (VL) E-mail: Veronique.Loizeau @ifremer.fr. ORCID iD: http://orcid.org/0000-0001-8038-9981 \\ ${ }^{4}$ Ifremer La Réunion, Rue Jean BERTHO - BP 60 - 97822 Le Port Cedex, France. \\ (DR) E-mail: David.Roos@ifremer.fr. ORCID iD: http://orcid.org/0000-0003-0273-3585
}

\begin{abstract}
Summary: The European hake, Merluccius merluccius, is an important resource for Mediterranean fisheries. This study focuses on juvenile and adult hake feeding ecology in the Gulf of Lions, using information from scientific surveys carried out during two seasons and three years (2004-2006). Stomach content and stable isotope $\left(\delta^{15} \mathrm{~N}, \delta^{13} \mathrm{C}\right)$ analyses were performed, and the main factors explaining variations in $\delta^{15} \mathrm{~N}$ were investigated using GLMs. In the Gulf of Lions, hake mostly fed on crustaceans and fish and a dominant piscivorous regime was reached at $15 \mathrm{~cm}$ total length. Pelagic fish (sardine, anchovy and small blue whiting) were the main source of prey $(40 \%-80 \%)$ and cannibalism was low $(<5 \%)$. The results confirmed that hake is an opportunistic feeder and also showed that the size and diversity of prey vary among hake size classes, probably as a result of the different spatial distribution and/or foraging migrations. The present study finally postulates that the unbalanced sex ratio ( $80 \%$ female against $20 \%$ male) observed at the adult stage could be related to the combination of growth pattern differences, diet and exploitation rate on the continental shelf, where the males spend a longer period of time.
\end{abstract}

Keywords: foodweb; GLM; habitat; Merluccius merluccius; predator-prey relationships; stable isotopes; stomach contents.

Ecología trófica de la merluza europea en el Golfo de León, Mediterráneo noroccidental

Resumen: La merluza europea, Merluccius merluccius, es un importante recurso para las pesquerías mediterráneas. Este estudio se centra en la ecología alimentaria de juveniles y adultos de merluza en el Golfo de León, utilizando información de campañas científicas llevadas a cabo en primavera y otoño durante tres años (2004-2006). Se realizaron análisis de contenidos estomacales e isótopos estables $\left(\delta^{15} \mathrm{~N}, \delta^{13} \mathrm{C}\right)$, mientras que la identificación de los principales factores que explican las variaciones en $\delta^{15} \mathrm{~N}$ se investigaron utilizando GLMs. En el Golfo de León, la merluza se alimenta mayoritariamente de crustáceos y peces y alcanzan un régimen piscívoro dominante a los $15 \mathrm{~cm} \mathrm{~T} \mathrm{~T}_{\mathrm{L}}$. Los peces pelágicos (sardina, anchoa y bacaladilla pequeña) constituyen el mayor porcentaje de sus presas (40-80\%) y el canibalismo es bajo $(<5 \%)$. Los resultados confirman que la merluza es un alimentador oportunista y también muestran que la talla y la diversidad de las presas varían entre distintas clases de talla de la merluza, probablemente como resultado de una distribución espacial diferente y/o migraciones en busca de alimento. Finalmente, este estudio postula que la proporción de sexos desequilibrada $(80 \%$ de hembras frente a $20 \%$ de machos) que se observa en estado adulto podría estar relacionada con la combinación de diferentes patrones de crecimiento, dieta y tasa de explotación en la plataforma continental, donde los machos pasan un mayor período de tiempo.

Palabras clave: red trófica; GLM; hábitat; Merluccius merluccius; relaciones depredador-presa; isótopos estables; contenidos estomacales.

Citation/Como citar este artículo: Mellon-Duval C., Harmelin-Vivien M., Métral L., Loizeau V., Mortreux S., Roos D., Fromentin J.-M. 2017. Trophic ecology of the European hake in the Gulf of Lions, northwestern Mediterranean Sea. Sci. Mar. 81(1): 7-18. doi: http://dx.doi.org/10.3989/scimar.04356.01A

Editor: P. Sartor.

Received: October 16, 2015. Accepted: November 29, 2016. Published: February 22, 2017.

Copyright: (๑) 2017 CSIC. This is an open-access article distributed under the terms of the Creative Commons Attribution (CC-by) Spain 3.0 License. 


\section{INTRODUCTION}

The Gulf of Lions (GoL) is a rather small area $\left(\sim 15000 \mathrm{~km}^{2}\right)$ of the northwestern Mediterranean that supports an intensive multi-specific fishery. European hake, Merluccius merluccius (Linnaeus, 1758), constitutes a significant part of the commercial landings in this area, and the stock is currently overexploited. Today only juvenile and young adult hake remain on the continental shelf after decades of intensive exploitation by bottom trawling (Jadaud et al. 2014). Hake is a permanent inhabitant of the GoL and lives in a wide bathymetric range (30-800 $\mathrm{m}$ depth), moving between the continental shelf, the shelf break and the slope during its life cycle (Recasens et al. 1998). The species spawns mainly on the shelf-break, where longline and gillnet fisheries target the largest individuals.

The role of hake in the GoL ecosystem is still poorly understood and the baseline information on its diet remains largely unknown, although this species is considered a key predator of this area. A shift in the main prey occurs from suprabenthic crustaceans to fish in the youngest juvenile stages (Bozzano et al. 1997, Ferraton et al. 2007); spatial and temporal diet variations have only been investigated for juveniles in the GoL (Ferraton et al. 2007). Size relationships between hake and its prey remain unknown in the GoL.

The objective of the present study is to provide new, detailed information on the feeding ecology of hake in the GoL, considering temporal, spatial and ontogenetic variability. To this end, stomach content and stable isotope $\left(\delta^{15} \mathrm{~N}, \delta^{13} \mathrm{C}\right)$ analyses were performed on individuals of hake caught during scientific surveys carried out in the GoL. Dietary studies based on stomach contents reflect the identifiable food ingested during the sampling period depending on the digestion rates of the prey. This approach was supplemented by the stable isotope analysis of nitrogen $\left({ }^{15} \mathrm{~N} /{ }^{14} \mathrm{~N}\right)$ and carbon $\left({ }^{13} \mathrm{C} /{ }^{12} \mathrm{C}\right)$. These indicators give an integrative signal of the food ingested over a longer period (weeks to months). Nitrogen is classically used as an indicator of trophic levels, as consumers are enriched in $\delta^{15} \mathrm{~N}$ relative to their food by a rather large fractionation factor (Minagawa and Wada 1984, Vander Zanden et al. 1997, Post 2002). In contrast, $\delta^{13} \mathrm{C}$ varies little along the foodweb and is used to identify baseline carbon sources at the base of the food chain (DeNiro and Epstein 1978, Cabana and Rasmussen 1994, Vander Zanden et al. 1997). Therefore, in addition to examining hake diet from stomach contents, we also analysed variations in $\delta^{15} \mathrm{~N}$ and $\delta^{13} \mathrm{C}$ to identify the main factors that could affect hake trophic ecology during its ontogeny in the GoL.

\section{MATERIALS AND METHODS}

\section{Data acquisition}

Sampling was carried out in the GoL, at four sites on the continental shelf selected from a previous work (Ferraton et al. 2007) and two new sites on the shelfbreak and upper-slope (Fig. 1). Zones 2 (in front of the Rhône River) and 4 were located at 30-50 m depth, zones 1 (under the influence of the Rhône river plume) and 3 at 70-100 m, and zones 5 and 6 at 150-250 m and 250-600 m, respectively. Sampling was performed during 14 surveys carried out between 2004 and 2006. Hake (stomach and muscle), prey (muscle), water particulate organic matter (POM), phytoplankton and zooplankton were collected on the continental shelf (zones 1 to 4) during spring and autumn 2004 and 2005 by diurnal standardized operations: bottom trawl (GOC 73 trawl, Anon. 2013), suprabenthic sledge (>0.5 mm), high-flow water pump for phytoplankton $(63-200 \mu \mathrm{m})$ and zooplankton triple nets $(>200 \mu \mathrm{m})$. On the shelfbreak (zone 5) and slope (zone 6), only hake and its main prey were collected from 2004 to 2006 by nocturnal gillnets $(30-38 \mathrm{~mm})$ with stretched mesh sizes. Note that no hauls were conducted in the 50-70 m and very few hauls in the 100-150 m depth ranges, because of the risk of damage to the sampling gear. Thus, the samples of hake (Fig. 2) are not representative of the

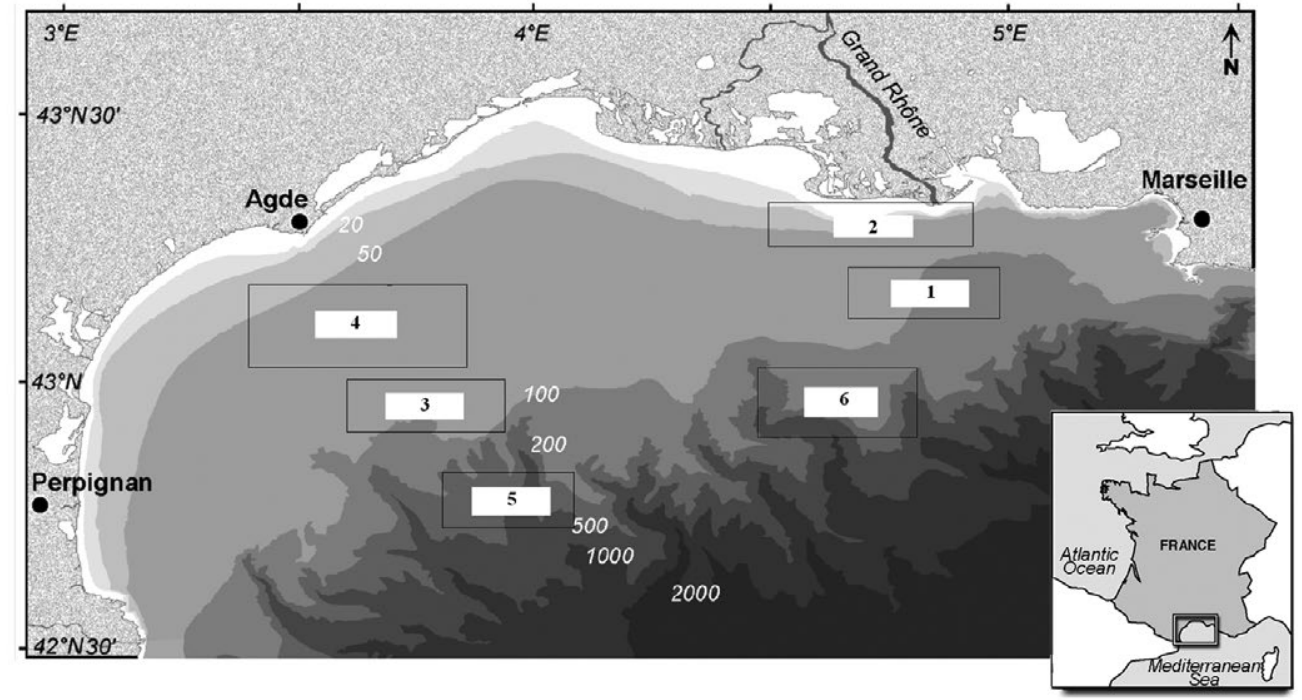

Fig. 1. - Map showing the location of sampling zones (hake and prey, 2004-2006) in the Gulf of Lions (box) in southern France. 
actual spatial distribution of individuals, in particular with regard to small hakes.

To study spatial and temporal fish prey variability in stomachs, a total of 154 hauls and 20 gillnet operations were performed. Fish were measured to the nearest $\mathrm{mm}$ of total length $\left(\mathrm{T}_{\mathrm{L}}\right)$ in small hakes $(<25 \mathrm{~cm})$ and to the nearest $\mathrm{cm} \mathrm{T}_{\mathrm{L}}$ for larger specimens. A total of 20 and 10 individuals per $\mathrm{cm}$ size class for small and large hakes, respectively, were randomly selected in each season, site and year, when available. A macroscopic maturity stage was attributed to each individual according to the gonad development. Small hakes were frozen at $-20^{\circ} \mathrm{C}$ immediately after the catch. Large hakes were dissected on board, stomachs were removed, and both were frozen at $-20^{\circ} \mathrm{C}$. Hake with everted or missing stomachs, the result of necrophagic activity, were excluded from the analyses of stomach contents. Small crustaceans living in the benthic boundary water layer were collected with a suprabenthic sledge equipped with zooplankton nets (0.5 $\mathrm{mm}$ mesh size) (Sorbe, 1999). All fish and crustacean species susceptible to being preyed upon by hake were collected and stored frozen as a whole at $-20^{\circ} \mathrm{C}$. Crustaceans were sorted by large taxonomic groups (mysids, amphipods, euphausiids) and frozen at $-20^{\circ} \mathrm{C}$. Surface water POM was pre-filtered on $250-\mu \mathrm{m}$ mesh sieves to remove zooplankton and large detritus, and filtered on preweighed Whatman $\mathrm{GF} / \mathrm{F}$ filters pre-combusted for 4 $\mathrm{h}$ at $500^{\circ} \mathrm{C}$. Phytoplankton was collected by pumping, with a submersible high-flow water pump $(320 \mathrm{~L}$ $\mathrm{min}^{-1}$ ), large volumes of seawater at the fluorescence maximum detected with a Seabird CTD fitted with a fluorimeter, through three different vertical nets of decreasing mesh size $(200,63$ and $6 \mu \mathrm{m})$ (HarmelinVivien et al. 2008). The term "phytoplankton" referred to the 63-200 $\mu \mathrm{m}$ fractions which mainly represented micro-phytoplankton. Zooplankton was sampled with zooplankton triple nets $(>200 \mu \mathrm{m})$ towed vertically (1 $\mathrm{m} \mathrm{sec}^{-1}$ ) in the entire water column.

\section{Diet and stable isotope analyses}

Stomachs were defrosted, weighed and fixed in $70 \%$ ethanol. Empty stomachs were counted and only used to calculate vacuity index (empty stomachs / empty stomachs + stomachs with food) or repletion index (1 - vacuity index) (Table 1$)$. Prey in stomachs were sorted, identified to the lowest taxonomic level possible, counted, measured in $\mathrm{mm} \mathrm{T}_{\mathrm{L}}$ and weighed (dry weight to the nearest $0.01 \mathrm{mg}$ recorded after 24 to $48 \mathrm{~h}$ at $60^{\circ} \mathrm{C}$, depending on the prey-type) individually or by broader taxonomic groups. Otoliths of fish prey were measured in $\mathrm{mm}$. Fish size vs otolith-size was calculated for each fish prey and used to estimate the $T_{L}$ of fish prey partly digested, and then a dry weight correction was made. The relative contribution in dry weight (W\%, Hyslop 1980) of each dietary category $\left(\mathrm{W}_{\mathrm{d}}\right)$ to the total dry weight of all prey categories $\left(\mathrm{W}_{\mathrm{dTOT}}\right)$ in the diet was used to describe hake feeding variations: $\mathrm{W}(\%)=\left[\mathrm{W}_{\mathrm{d}} / \mathrm{W}_{\mathrm{dTOT}}\right] * 100$. This index was chosen, as weight is the best proxy of the energy provided by a prey to a predator (Tyler 1972).
Stable isotope analyses (SIA) were conducted on two sub-samples of surface POM and the 63- to 200-um-sized fraction. One sub-sample was analysed without any prior treatment for $\delta^{15} \mathrm{~N}$ determination. The other, used for $\delta^{13} \mathrm{C}$ analysis, was acidified with $1 \% \mathrm{HCl}$ solution to remove carbonates, rinsed with distilled water and oven-dried at $40^{\circ} \mathrm{C}$ for $24 \mathrm{~h}$, as carbonates have a higher $\delta^{13} \mathrm{C}$ than organic carbon (DeNiro and Epstein 1978, Lorrain et al. 2003). SIA on fish and crustaceans were conducted on the same samples as those for stomach analysis between 2004 and 2006. Samples of muscle posterior to the head for fish, of caudal muscle for shrimp and of whole organisms for zooplankton and suprabenthos were used for SIA. Muscle samples were oven-dried and ground into a powder with a mortar and pestle. Crustaceans were decalcified and samples were divided into two sub-samples and treated as surface POM. Samples of large crustaceans and fish were analysed individually, whereas samples of small crustaceans were pooled to obtain enough material for analysis. Powdered samples were weighed $(\sim 1 \mathrm{mg})$ into tin capsules and combusted in a Europa 20:20 continuous-flow isotope-ratio mass spectrometer (Mylnefield Research Services-SCRI, Scrimgeour and Robinson 2003). Based on standard deviation of within-run replicate measurements of standards, analytical error was estimated to be $\pm 0.2 \%$ o for $\delta^{13} \mathrm{C}$ and $\delta^{15} \mathrm{~N}$ measurements. Stable isotope values are expressed in the standard $\delta$-notation as parts per thousand $(\% \circ)$ relative to Vienna Pee Dee Belemnite $\left(\delta^{13} \mathrm{C}\right)$ and atmospheric air $\left(\delta^{15} \mathrm{~N}\right)$ standards. SIA were limited to the prey size range consumed by hake. When a large prey size range was consumed, different lengthcategories were considered.

Lipids were not extracted from our samples prior to SIA. The mean level of lipids $(\%)$ in muscle measured over 64 individuals $(5-71 \mathrm{~cm})$ was estimated to $5.17 \% \pm 2.67 \%$. This mean value close to $5 \%$ can be considered as a low lipid concentration inducing no bias on $\delta^{13} \mathrm{C}$ values (Post et al. 2007).

The hake trophic foodweb was established from the mean $( \pm \mathrm{SE}) \delta^{15} \mathrm{~N}$ and $\delta^{13} \mathrm{C}$ values of hake and its different prey only for the year 2005 because it was the most complete year for isotopic data (Table 2). Two main sources of organic matter, the marine phytoplankton and the Rhône River POM, were identified in this area.

\section{Statistical analyses}

To evaluate ontogenetic changes in hake diet composition, a hierarchical agglomerative cluster analysis was performed on the dry weight percentages (W\%) of each dietary category of each size class (using Euclidean distance and Ward's minimum-variance method). Hake were grouped by $2-\mathrm{cm} \mathrm{T}_{\mathrm{L}}$ class until $24 \mathrm{~cm}$ and by $5-\mathrm{cm} \mathrm{T}_{\mathrm{L}}$ class afterwards. The spatial and temporal variations in hake diet were examined by comparing $\mathrm{W} \%$ of each prey category in the resulting length groups defined by the cluster analysis.

To study the relationship between the ontogenetic changes in prey size and hake size, we used simple linear regression analysis, and we used quantile regres- 
10 Mellon-Duval C. et al.

Table 1. - Diet composition of hake according to size (total length, cm) from the GoL in 2004-2006, expressed as percentage by dry weight of each prey category (W\%). Total number of stomachs included stomachs with and without food, stomachs regurgitated, and stomachs not found because they were eaten by necrophages during the catch. (*, values $<0.1 \%$; -, prey category not found). Unid., unidentified.

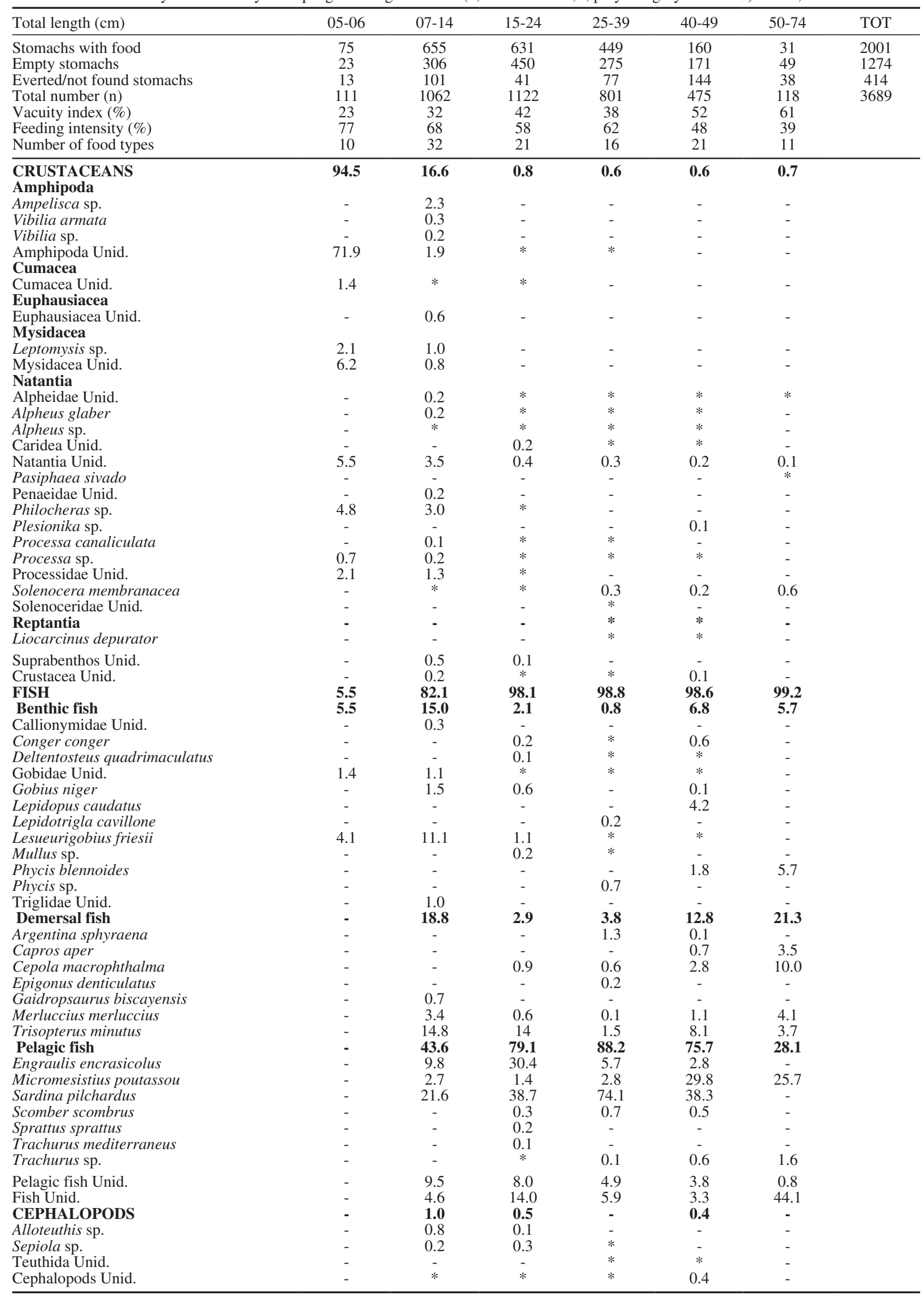


Table 2. - Number of $\delta^{15} \mathrm{~N}$ samples per hake size class, year and season.

\begin{tabular}{ccccccc}
\hline \multirow{2}{*}{$\begin{array}{c}\text { Hake size } \\
\text { classes }\end{array}$} & \multicolumn{2}{c}{2004} & \multicolumn{2}{c}{2005} & \multicolumn{2}{c}{2006} \\
& spring & autumn & spring & autumn & spring & autumn \\
\hline $5-6$ & 11 & 2 & 8 & - & - & - \\
$7-14$ & 49 & 37 & 32 & 23 & - & - \\
$15-24$ & - & 10 & 8 & 10 & - & - \\
$17-25$ & 34 & 30 & 32 & 30 & - & - \\
$25-39$ & 65 & 51 & 98 & 78 & - & 13 \\
$40-49$ & 29 & 14 & 37 & 20 & - & 74 \\
$50-74$ & 19 & 3 & 9 & 5 & - & 61 \\
\hline
\end{tabular}

sions to estimate changes in minimum and maximum prey size. Quantiles ranged between the $90^{\text {th }}$ and $99^{\text {th }}$ for upper bound and the $1^{\text {st }}$ and $10^{\text {th }}$ for the lower bound.

We also investigated variations in hake $\delta^{15} \mathrm{~N}$ based on all available isotopic data (2004-2006) and tested the potential influence of different factors (season, depth, east-west gradient, sex) and continuous variables (length, condition, $\delta^{13} \mathrm{C}$ ) as well as potential interactions between these explanatory variables, using generalized linear models (Venables and Dichmont 2004). Because the adults and the juveniles are not sympatric and because juveniles were not collected on the shelf-break and the upper-slope (Fig. 2), we performed one model for the juveniles and another for the adults. Both models included all factors and variables, but sex was added as a supplementary factor for the model on adults. Interactions between factors and variables were also tested and presented only when significant. As $\delta^{15} \mathrm{~N}$ is a continuous positive variable that is not normally distributed, we chose a Gamma error distribution with an identity link function. Diagnostic plots including the predicted values of mean of response and the standardized Pearson residuals, as well as the correlation among parameters, were examined for each analysis performed. The Akaike information criterion (AIC) was used to select the final model.

Hake maturity was identified according to two categories: juvenile or adult. Fish were considered as juvenile when the attributed maturity stage was virgin or at the beginning of maturation. Male adult stages were defined from the maturity scale used during the MEDITS surveys (Anon., 2013). Female adult stages were defined from gonadosomatic index (GSI) calculated as GSI $=100(\mathrm{GW} / \mathrm{W})$, where GW is the gonad wet weight and $\mathrm{W}$ is the observed individual eviscerated weight.

Fish condition was estimated by the relative condition factor, Kn, proposed by Le Cren (1951, see also Froese 2006) computed as $\mathrm{Kn}=\mathrm{W} / \mathrm{aL}^{\mathrm{n}}$, where $\mathrm{W}$ is the observed individual eviscerated weight, $\mathrm{L}$ is the $\mathrm{T}_{\mathrm{L}}$ in $\mathrm{cm}$, and $\mathrm{aL}^{\mathrm{n}}$ is the estimated eviscerated weight from the $\log _{10} \mathrm{~W}-\log _{10} \mathrm{~L}$ relationship, where: $\mathrm{aL}^{\mathrm{n}}=10^{\text {-intercept }}$ $\mathrm{T}_{\mathrm{L}}$ slope. In the original formula, $\mathrm{W}$ was the total weight of the fish, but we considered the eviscerated weight for two reasons: (i) the weight of stomach content is highly variable and can therefore bias the estimation of the relation $\mathrm{aL}^{\mathrm{n}}$; and (ii) the condition is here used as an explanatory variable of $\delta^{15} \mathrm{~N}$ in hake muscle.

Statistical analyses were performed with the support of SPSS 17 (SPSS 2008) and R Softwares (R Development Core Team 2009).

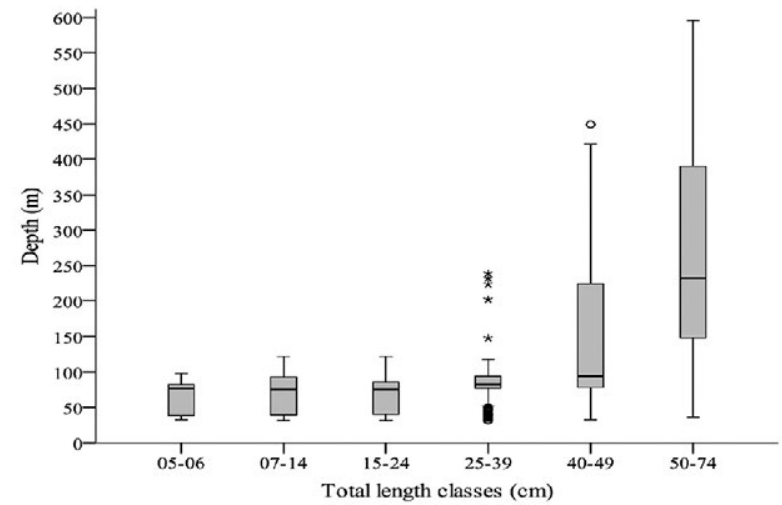

Fig. 2. - Spatial distribution of the samples of hake in the GoL in 2004-2006 $(n=2483$, min depth=31 m, max depth=596 m).

\section{RESULTS}

\section{Hake diet}

Among the 3689 hake sampled, 2001 showed stomachs with food, 1274 empty stomachs (39\%) and 414 stomachs regurgitated or not found because they were eaten by necrophages. The vacuity index increased with length (23\% to $61 \%$, Table 1$)$. Larger individuals that displayed empty stomachs more frequently (61\%) were caught in deeper waters (down to $600 \mathrm{~m}$, Fig. 2). Fish contribution in hake diet increased with hake length from $5.5 \%$ to $99.2 \%$ (Table 1). Crustaceans were the dominant food in the smallest individuals and cephalopods never exceeded $1 \%$. The results of cluster analysis clearly differentiated six groups of diet size classes (Fig. 3), confirming the changes in hake diet during its growth. The smallest size class $\left(5-6 \mathrm{~cm} \mathrm{~T}_{\mathrm{L}}\right.$, a singleton) included a low number of prey types (10), mostly crustaceans $(94.5 \%)$ with a high contribution of amphipods $(71.9 \%)$. By contrast, the second smallest group in size (7-14 $\mathrm{cm} \mathrm{T}_{\mathrm{L}}$ ) displayed the most diversified diet (32 prey types). Benthic and demersal fish species were nearly as important (33.8\%) as pelagic fishes (43.6\%), while crustaceans were clearly less important (16.6\%). The following groups (hake of 15-24, 25-39 and 40-49

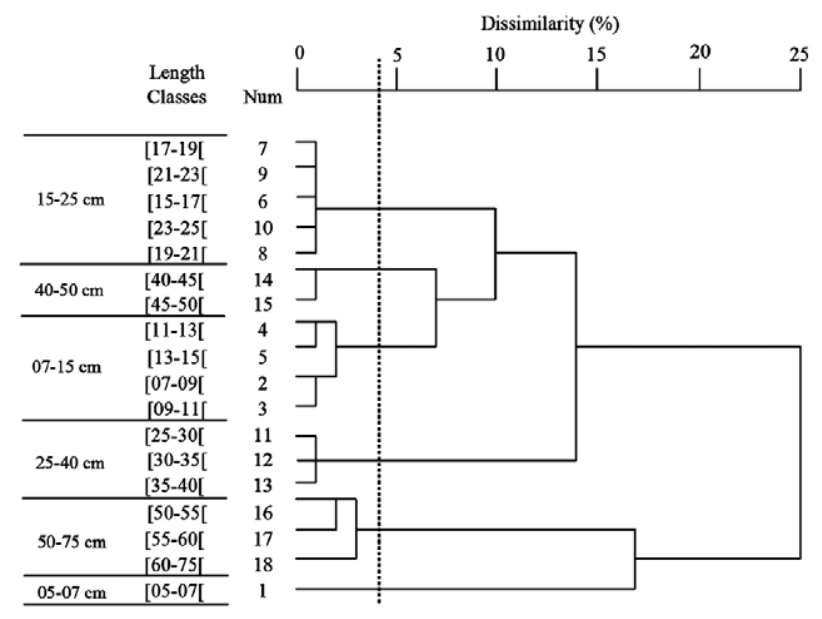

Fig. 3. - Dendrogram representing hake dietary similarity according to size classes, on the basis of mean percentage contribution $(\mathrm{Cp}$ : W\%) of each food category. 

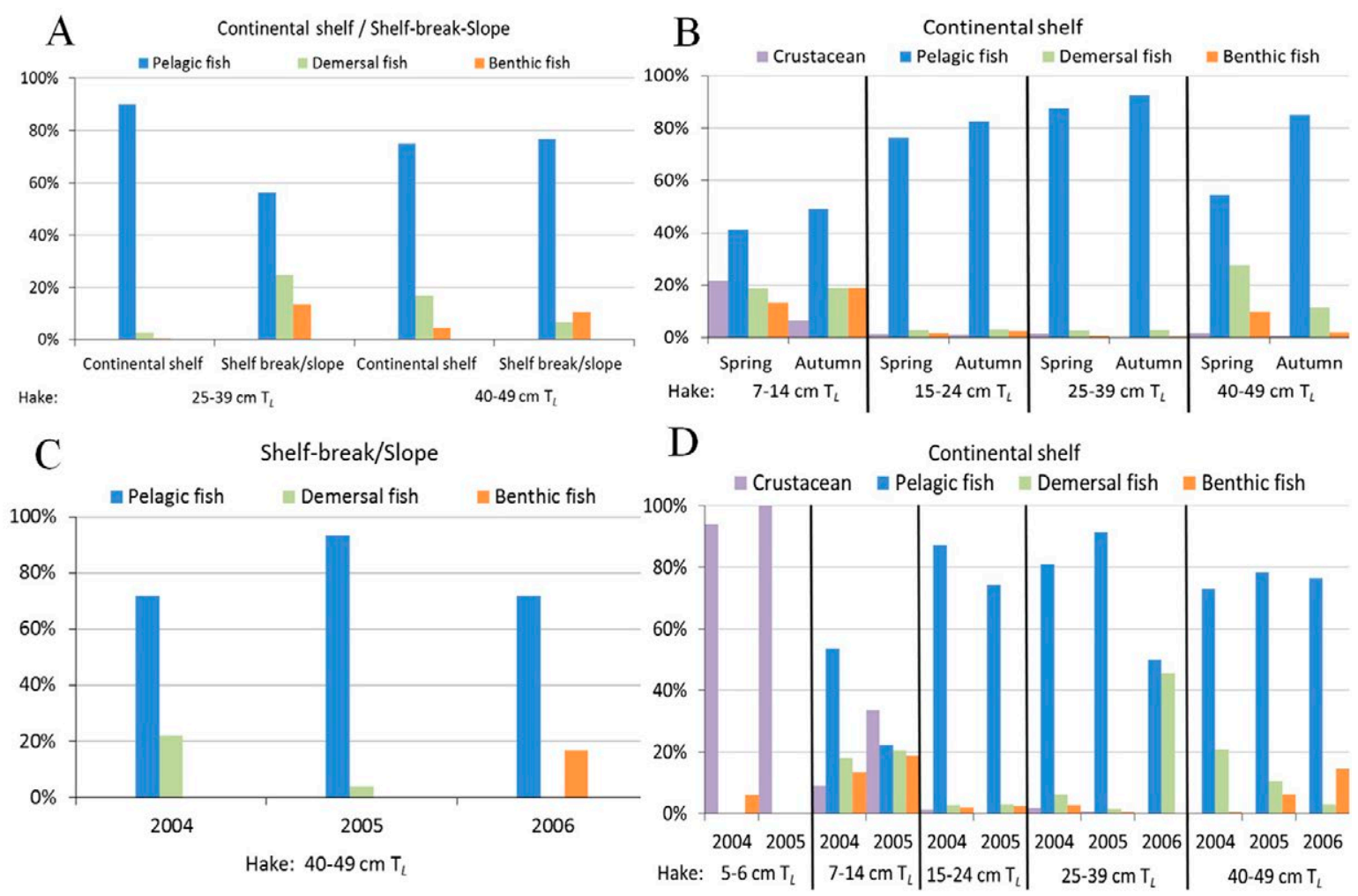

Fig. 4. - Spatio-temporal feeding variations of main prey groups according to (A) depth, (B) season, (C-D) year.

cm $\mathrm{T}_{\mathrm{L}}$ ) exhibited 16 to 21 prey types, including mostly fish $(>98 \%)$, mostly pelagic species $(75.7-88.2 \%)$. In the largest group $(50-74 \mathrm{~cm})$, the number of prey types decreased to 11 (similar to the smallest fish group) and the diet was mostly composed of fish $(99.2 \%)$, among which $28.1 \%$ were pelagic, $21.3 \%$ demersal and $5.7 \%$ benthic (the remaining part of the fish diet could not be determined).

Only three pelagic fish, sardine (Sardina pilchardus Walbaum, 1792), European anchovy (Engraulis encrasicolus Linnaeus, 1758) and small blue whiting ( $\mathrm{Mi}$ cromesistius poutassou Risso 1827), two demersal fish, poor cod (Trisopterus minutus Linnaeus, 1758) and red bandfish (Cepola macrophthalma Linnaeus, 1758), and two benthic fish, Lesueurigobius friesii (Malm, 1874), and the greater forkbeard (Phycis blennoides Brünnich, 1768), exceeded individually more than $5 \%$ of dry weight of hake diet (Table 1). The contribution of the three main pelagic fish species varied with hake length (Table 1). Sardine predominated in hake ranging from 7 to $49 \mathrm{~cm} \mathrm{~T}_{\mathrm{L}}(21-74 \%)$, while anchovy only prevailed in the $15-24 \mathrm{~cm} \mathrm{~T}_{\mathrm{L}}$ size class (30\%) and small blue whiting in fish larger than $39 \mathrm{~cm} \mathrm{~T}_{\mathrm{L}}(26-30 \%)$. The other groups never exceeded $15 \%$. Cannibalism was observed in all size classes displaying a piscivorous diet, but remained low $(0.1$ to $4.1 \%)$. It was higher in the smallest size class $(3.4 \%)$ and in the largest hake $(4.1 \%)$, with a maximum rate on the slope $(6 \%)$.

\section{Spatio-temporal feeding variations}

Because all hake size classes did not occur in all depth ranges, seasons and years, the influence of these factors on hake diet were examined with separate data sets (Fig. 4A-D).

The effect of depth (continental shelf vs shelf-break/ slope) on the diet was analysed on $25-49 \mathrm{~cm} \mathrm{~T}_{\mathrm{L}}$ ( 2 size classes) (Fig. 4A). In the first size class $\left(25-39 \mathrm{~cm} \mathrm{~T}_{\mathrm{L}}\right)$, pelagic fish was the main prey $(90 \%)$ on the continental shelf, while hake consumed $2 / 3$ pelagic fish and $1 / 3$ demersal or benthic fish on the shelf-break/slope. Sardine was the main prey on the continental shelf (77\%), while small blue whiting dominated on the shelf-break/ slope $(42 \%)$. In the second size class $\left(40-49 \mathrm{~cm} \mathrm{~T} \mathrm{~T}_{\mathrm{L}}\right.$ ), there was no difference in the proportion of pelagic fish or in the proportion of demersal or benthic fish between the two areas. Nonetheless, sardine also dominated hake diet on the continental shelf (63\%), while small blue whiting dominated in deeper waters $(74 \%)$.

The analysis of dietary changes with season (spring vs autumn) was only possible on the continental shelf for 7-49 $\mathrm{cm} \mathrm{T}_{\mathrm{L}}$ (4 size classes) (Fig. 4B). Considering pelagic fish, there was no significant difference between seasons in the first three size classes (7-14 $\mathrm{cm}, 15-24 \mathrm{~cm}$ and $25-39 \mathrm{~cm} \mathrm{~T}_{\mathrm{L}}$ ), but the proportion of pelagic fish was $30 \%$ lower in spring than in autumn in the largest size class $\left(40-49 \mathrm{~cm} \mathrm{~T}_{\mathrm{L}}\right)$. Crustaceans were only preyed on by the $7-14 \mathrm{~cm} \mathrm{~T}_{\mathrm{L}}$ class, especially in spring. Total fish prey represented $73 \%$ in spring and $87 \%$ in autumn in this size class. Demersal or benthic fish dominated more in spring $(37 \%)$ than in autumn $(13 \%)$ in the $40-49 \mathrm{~cm} \mathrm{~T}_{\mathrm{L}}$ class.

Year-to-year variations were analysed separately on the shelf-break/slope in only one size class (40-49 $\left.\mathrm{cm} \mathrm{T}_{\mathrm{L}}\right)$ and on the continental shelf $\left(5-49 \mathrm{~cm} \mathrm{~T}_{\mathrm{L}}\right)$ in 5 size classes (Fig. 4C-D). On the shelf-break/slope 


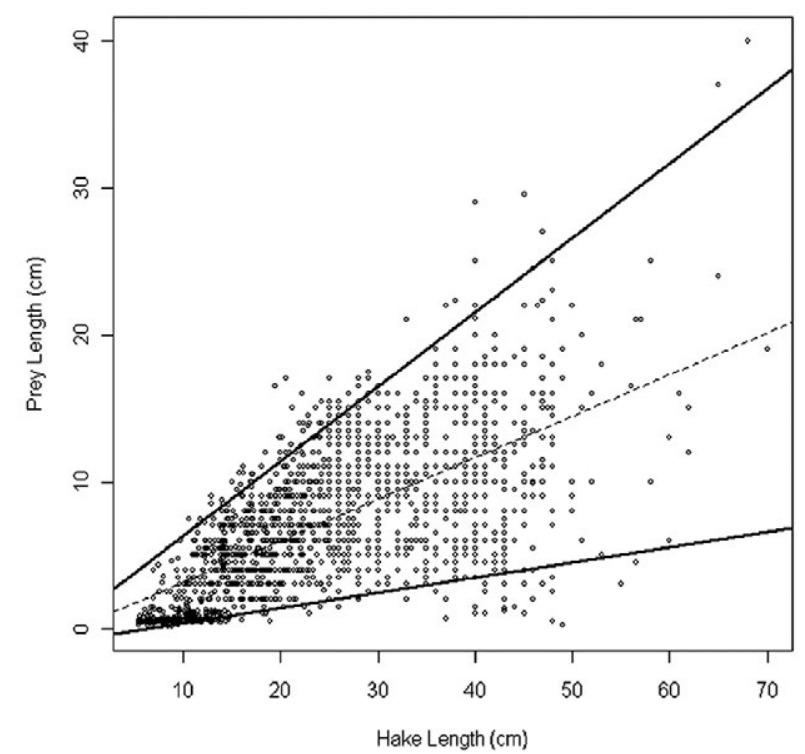

Fig. 5. - Hake size-prey size scatter diagram. Ontogenetic changes in prey sizes consumed with increasing hake size for all prey combined. Continuous lines, minimum ( $5^{\text {th }}$ quantile) and maximum $\left(95^{\text {th }}\right.$ quantile) prey sizes estimated by quantile regression; dashed line, mean prey sizes estimated by least-square regression; $n=1702$.

(Fig. 4C), where small blue whiting largely dominated ( $>70 \%$ the pelagic fish group in the diet of the 40-49 $\mathrm{cm} \mathrm{T}_{\mathrm{L}}$ class, there was no difference between 2004 and 2006 in the proportion of pelagic fish $(72 \%)$ or demersal/benthic fish (20\%). On the continental shelf (Fig. 4D), there were no major differences between years in the respective proportion of pelagic fish, demersal fish and crustaceans, except in the 7-14 cm and the 25-39 $\mathrm{cm} \mathrm{T}_{\mathrm{L}}$ classes. In the 7-14 $\mathrm{cm} \mathrm{T}_{\mathrm{L}}$ class, the proportion of small pelagics (54\%) dominated in 2004 and the proportion of crustaceans (33\%) increased in 2005. In the $25-39 \mathrm{~cm} \mathrm{~T} \mathrm{~T}_{\mathrm{L}}$ class, the proportions of small pelagics represented more than 80\% in 2004 and 2005, but only $50 \%$ in 2006 . Yearly diet changes were mainly observed at the level of the dominant crustaceans in the smallest size classes $\left(5-6 \mathrm{~cm} \mathrm{~T} \mathrm{~T}_{\mathrm{L}}\right.$ ): amphipods dominated in 2004 (78\%), whereas natantia decapods $(55 \%)$ and mysids (45\%) prevailed in 2005.

\section{Prey-predator length relationships}

The range of prey sizes consumed by hake increased significantly with increasing fish size $\left(R^{2}=0.653\right.$, $\mathrm{N}=1702, \mathrm{P}<0.0001$, Fig. 5). The slopes of the extreme bounds $\left(5^{\text {th }}-95^{\text {th }}\right.$ quantiles $)$ of prey size distribution were also significant $(\mathrm{P}<0.0001)$, but of a different amplitude (the slope was higher for the $95^{\text {th }}$ quantile than for the $5^{\text {th }}$ one, Fig. 5). Hake 5-6 $\mathrm{cm} \mathrm{T}_{\mathrm{L}}$ class fed on a mean length prey of $0.7 \pm 0.05 \mathrm{~cm} \mathrm{~T}_{\mathrm{L}}$ and the following

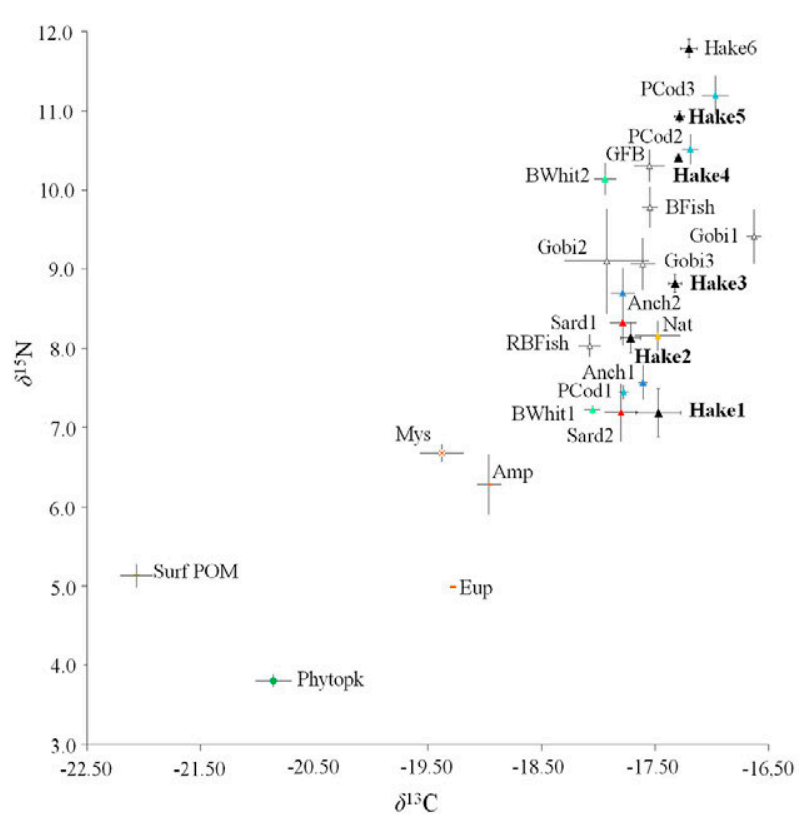

Fig. 6. - Mean $\left( \pm\right.$ SE) values of $\delta^{15} \mathrm{~N}(\% \circ)$ and $\delta^{13} \mathrm{C}(\% \circ)$ for main prey of hake trophic web in the GoL in 2005. Codes: Surf POM, Surface Particulate Organic Matter; Phytopk, Phytoplankton; Zoopk, Zooplankton; Amp, Amphipods; Eup, Euphausiids; Mys, Mysids; Nat, Natantia; Hake1, Hake 5-6 cm; Hake2, Hake 7-14 cm; Hake3, Hake 15-24 cm; Hake4, Hake 25-39 cm; Hake5, Hake 40-49 cm; Hake6, Hake 50-74 cm; Gob1, Deltentosteus quadrimaculatus; Gob2, Gobius niger; Gob3, Lesueurigobius friesii; GFB, Greater Forkbeard; BFish, Boar Fish; RBFish, Red Bandfish; Sard1, Sardine $<13.5 \mathrm{~cm}$; Sard2, Sardine $\geq 13.5 \mathrm{~cm}$; Anch1, Anchovy $<14 \mathrm{~cm}$; Anch2, Anchovy $\geq 14 \mathrm{~cm}$; BWhit1=Blue Whiting $<15 \mathrm{~cm}$; BWhit2, Blue Whiting $\geq 15 \mathrm{~cm}$; PCod1, Poor Cod $\leq 7 \mathrm{~cm}$; PCod2, Poor Cod $8-13 \mathrm{~cm}$; PCod3, Poor Cod $\geq 14 \mathrm{~cm}$.

size classes fed on $2.6 \pm 0.1 \mathrm{~cm}, 6.6 \pm 0.15 \mathrm{~cm}, 9.9 \pm 0.15$ $\mathrm{cm}, 11.4 \pm 0.4 \mathrm{~cm}$ and $15.2 \pm 1.7 \mathrm{~cm} \mathrm{~T}_{\mathrm{L}}$, respectively. However, hake was able to ingest larger prey, $\geq 2 / 3$ of its body size in the case of the red bandfish $(C$. macrophthalma). Hake size classes fed on different mean lengths of the main fish prey such as gobids, anchovy, sardine, blue whiting and poor cod (Table 3).

\section{Hake trophic web}

The hake trophic web was based on a marine phytoplankton source and represented a continuum of feeding types ranging from crustaceans to pelagic, benthic and demersal fish (Fig. 6). As expected, phytoplankton and suprabenthic crustaceans (amphipods, euphausiids, and mysids) displayed the lowest $\delta^{15} \mathrm{~N}$ and $\delta^{13} \mathrm{C}$ values. Stable isotope ratios of the main prey types of hake ranged from $5 \%$ o to $11.2 \%$ or for $\delta^{15} \mathrm{~N}$ and from $-20.3 \%$ o to $-16.9 \%$ ofor $\delta^{13} \mathrm{C}$ (Table 4). The smallest size classes of fish prey displayed a lower $\delta^{15} \mathrm{~N}$ value than the largest ones, except for sardine. The largest sardine $(\geq 13.5$ Table 3. - Mean size \pm SE of the main fish prey eaten per hake size class.

\begin{tabular}{c|c|c|c|c|}
\hline Hake size classes $(\mathrm{cm})$ & Gobid sp. & Anchovy & Sardine & Blue whiting \\
\hline $7-14$ & $3.9 \pm 0.2$ & $6.6 \pm 0.4$ & $5.8 \pm 0.3$ & $7.5 \pm 0.3$ \\
$15-24$ & $4.7 \pm 0.4$ & $9.0 \pm 0.2$ & $8.1 \pm 0.3$ & $10.8 \pm 1.4$ \\
$25-39$ & $5.1 \pm 0.6$ & $9.0 \pm 0.4$ & $12.7 \pm 0.2$ & $11.3 \pm 0.9$ \\
$40-49$ & $6.0 \pm 1.2$ & $8.1 \pm 1.0$ & $13.3 \pm 0.4$ & $14.7 \pm 0.7$ \\
$50-74$ & & & & $18.6 \pm 1.4$ \\
\hline
\end{tabular}


Table 4. - Mean isotopic signature with standard error (SE) by size class (SC) in the GoL in 2005.

\begin{tabular}{|c|c|c|c|c|c|c|c|}
\hline & \multirow[b]{2}{*}{$\mathrm{SC}(\mathrm{cm})$} & \multirow{2}{*}{ Code } & \multirow[b]{2}{*}{$\mathrm{n}$} & \multicolumn{2}{|c|}{$\delta^{15} \mathrm{~N}(\% \circ)$} & \multicolumn{2}{|c|}{$\delta^{13} \mathrm{C}(\% \circ)$} \\
\hline & & & & mean & SE & mean & $\mathrm{SE}$ \\
\hline Surface Particulate Organic Matter & & Surf POM & 55 & 5.13 & 0.15 & -22.07 & 0.14 \\
\hline Phytoplankton. & & Phytopk & 24 & 3.80 & 0.08 & -20.86 & 0.16 \\
\hline Zooplankton & & Zoopk & 6 & 6.71 & 0.63 & -21.41 & 0.31 \\
\hline Amphipods & & Amp & 9 & 6.28 & 0.38 & -20.34 & 0.11 \\
\hline Euphausiids & & Eup & 3 & 4.99 & 0.03 & -19.96 & 0.02 \\
\hline Mysids & & Mys & 9 & 6.68 & 0.11 & -20.34 & 0.19 \\
\hline Natantia & & Nat & 41 & 8.16 & 0.19 & -17.90 & 0.20 \\
\hline Deltentosteus quadrimaculatus & 8 & Gob1 & 19 & 9.41 & 0.34 & -16.92 & 0.06 \\
\hline Gobius niger & 11 & Gob2 & 16 & 9.10 & 0.66 & -18.12 & 0.37 \\
\hline Lesueurigobius friesii & 6.4 & Gob3 & 29 & 9.06 & 0.32 & -17.87 & 0.11 \\
\hline Phycis blennoides & 15.7 & GFHake & 6 & 10.31 & 0.20 & -17.55 & 0.13 \\
\hline Capros aper & 13 & BFish & 8 & 9.78 & 0.26 & -17.82 & 0.07 \\
\hline Cepola macrophthalma & 25.8 & RBFish & 15 & 8.05 & 0.15 & -18.41 & 0.06 \\
\hline Sardina pilchardus & $<13.5$ & Sard1 & 19 & 8.32 & 0.28 & -18.08 & 0.12 \\
\hline Sardina pilchardus & $\geq 13.5$ & Sard2 & 28 & 7.19 & 0.36 & -18.74 & 0.15 \\
\hline Engraulis encrasicolus & $<14$ & Anch1 & 39 & 7.57 & 0.22 & -17.84 & 0.04 \\
\hline Engraulis encrasicolus & $\geq 14$ & Anch2 & 10 & 8.70 & 0.32 & -18.09 & 0.10 \\
\hline Micromesistius poutassou & $<15$ & BWhit1 & 28 & 7.22 & 0.05 & -18.28 & 0.07 \\
\hline Micromesistius poutassou & $\geq 15$ & BWhit2 & 19 & 10.14 & 0.20 & -17.93 & 0.10 \\
\hline Trisopterus minutus & $\leq 7$ & PCod1 & 11 & 7.45 & 0.09 & -17.99 & 0.04 \\
\hline Trisopterus minutus & $8-13$ & $\mathrm{PCod} 2$ & 40 & 10.51 & 0.19 & -17.36 & 0.07 \\
\hline Trisopterus minutus & $\geq 14$ & PCod3 & 24 & 11.19 & 0.25 & -17.11 & 0.12 \\
\hline Merluccius merluccius & $5-6$ & Hake 1 & 8 & 7.19 & 0.30 & -17.67 & 0.20 \\
\hline Merluccius merluccius & $7-14$ & Hake2 & 55 & 8.13 & 0.19 & -17.85 & 0.09 \\
\hline Merluccius merluccius & $15-24$ & Hake3 & 80 & 8.82 & 0.11 & -17.45 & 0.06 \\
\hline Merluccius merluccius & $25-39$ & Hake4 & 176 & 10.41 & 0.05 & -17.44 & 0.02 \\
\hline Merluccius merluccius & $40-49$ & Hake5 & 57 & 10.93 & 0.07 & -17.44 & 0.04 \\
\hline Merluccius merluccius & $50-74$ & Hake6 & 14 & 11.79 & 0.12 & -17.32 & 0.07 \\
\hline
\end{tabular}

Table 5. - Stepwise generalized linear model for factors and continuous variables controlling $\delta^{15} \mathrm{~N}$ variability in juvenile (A) and adult (B) hakes in the GoL. Parameter estimates (c) and standard error for the best fitting GLMs model.

\begin{tabular}{|c|c|c|c|c|c|c|c|c|c|c|}
\hline $\begin{array}{l}\text { Factors and continu- } \\
\text { ous variables } \\
\text { added }\end{array}$ & $\mathrm{c}$ & SE & Residual $d f$ & Deviance & Df & $\begin{array}{l}\text { Deviance } \\
\text { decrement }\end{array}$ & $\begin{array}{c}\text { Cumulative } \\
\text { deviance } \\
\text { explained }\end{array}$ & $\begin{array}{l}\% \text { of total } \\
\text { deviance } \\
\text { explained }\end{array}$ & $\begin{array}{l}\text { P-value } \\
\text { (chi- } \\
\text { squared) }\end{array}$ & $\mathrm{AIC}$ \\
\hline A: Juvenile & & & & & & & & & & \\
\hline Intercept & 5.056 & .1893 & 497 & 12.407 & & & & & & 1798 \\
\hline + Length & .127 & .0035 & 496 & 6.194 & 1 & 6.213 & 50.077 & $65 \%$ & 0.000 & 1453 \\
\hline + Season & 2.678 & .1387 & 495 & 4.579 & 1 & 1.615 & 63.093 & $17 \%$ & 0.000 & 1305 \\
\hline + Season*Length & -.073 & .0060 & 494 & 3.160 & 1 & 1.419 & 74.531 & $15 \%$ & 0.000 & 1122 \\
\hline + Depth & & & 492 & 2.850 & 2 & 0.310 & 77.029 & $3 \%$ & 0.000 & 1074 \\
\hline $\begin{array}{l}\text { + E-W gradient } \\
\text { B: Adult }\end{array}$ & .217 & .0626 & 491 & 2.783 & 1 & 0.067 & 77.569 & $1 \%$ & 0.001 & 1064 \\
\hline Intercept & 7.132 & .3442 & 334 & 1.197 & & & & & & 648 \\
\hline + Length & .061 & .0042 & 333 & 0.931 & 1 & 0.266 & 22.222 & $44 \%$ & 0.000 & 566 \\
\hline+ Season & -.461 & .0551 & 332 & 0.777 & 1 & 0.154 & 35.087 & $25 \%$ & 0.000 & 507 \\
\hline+ Depth & .449 & .0789 & 331 & 0.693 & 1 & 0.084 & 42.105 & $14 \%$ & 0.000 & 471 \\
\hline$+\operatorname{Sex}$ & -.404 & .0654 & 330 & 0.621 & 1 & 0.072 & 48.120 & $12 \%$ & 0.000 & 436 \\
\hline + Condition & 1.086 & .3214 & 329 & 0.601 & 1 & 0.02 & 49.791 & $3 \%$ & 0.001 & 427 \\
\hline + E-W gradient & .143 & .0511 & 328 & 0.587 & 1 & 0.014 & 50.960 & $2 \%$ & 0.005 & 422 \\
\hline
\end{tabular}

$\mathrm{cm} \mathrm{T}_{\mathrm{L}}$ ) displayed the most depleted $\delta^{13} \mathrm{C}$ signature, just above phytoplankton and the suprabenthic crustaceans, which probably represented a large part of their diet. The lowest $\delta^{15} \mathrm{~N}$ values (7.2\%o) were found in the largest sardine $\left(\geq 13.5 \mathrm{~cm} \mathrm{~T}_{\mathrm{L}}\right)$, in the smallest blue whiting $\left(<15 \mathrm{~cm} \mathrm{~T}_{\mathrm{L}}\right)$ and in the smallest hake $\left(5-6 \mathrm{~cm} \mathrm{~T} \mathrm{~T}_{\mathrm{L}}\right)$. The small anchovy and poor cod showed slightly higher $\delta^{15} \mathrm{~N}$ values $\left(7.5 \% 0^{-8} \%\right.$ ) , followed by large anchovy, small sardine, red bandfish and hake 7-24 $\mathrm{cm} \mathrm{T}_{\mathrm{L}}$ class (8\%o-9\%o), and then by gobiids and boarfish (Capros aper Linnaeus, 1758) ([9-10\%o[). Finally, the largest blue whiting $\left(\geq 15 \mathrm{~cm} \mathrm{~T}\right.$ ), poor cod $\left(\geq 8 \mathrm{~cm} T_{L}\right)$, hake $\left(\geq 25 \mathrm{~cm} \mathrm{~T}_{\mathrm{L}}\right)$ and the greater forkbeard exhibited the highest $\delta^{15} \mathrm{~N}$ values $(\geq 10 \%$ o). A continuous increase in $\delta^{15} \mathrm{~N}$ with length was thus observed in hake, from $7.2 \%$ o to $11.8 \%$ o. A slight increase $\left(0.4 \%\right.$ ) in hake $\delta^{13} \mathrm{C}$ with length occurred from the smallest $(-17.7 \%$ ) to the largest individuals $(-17.3 \%$ ) .

\section{Hake $\delta^{15} \mathbf{N}$ variation}

This analysis was based on 892 isotope samples. All factors (season, depth, E-W gradient), two continuous variables (size and $\delta^{13} \mathrm{C}$ ) and one interaction (season-length) were highly significant $(\mathrm{P}<0.001)$ in the selected model for juveniles, but $\delta^{13} \mathrm{C}$ was finally removed because of high correlation with the intercept (Table 5A). The length factor showed the highest contribution to the total explained deviance $(50 \%)$ of hake $\delta^{15} \mathrm{~N}$ variability, followed by season (13\%), season-length interaction (11\%), depth (2\%) and E-W gradient $(1 \%)$.

The model selected for adults was similar to that of juveniles, but it also included the condition and sex as significant covariates, while the length-season interaction did not appear to be significant (Table 5B). Length had again the greatest contribution to hake $\delta^{15} \mathrm{~N}$ vari- 

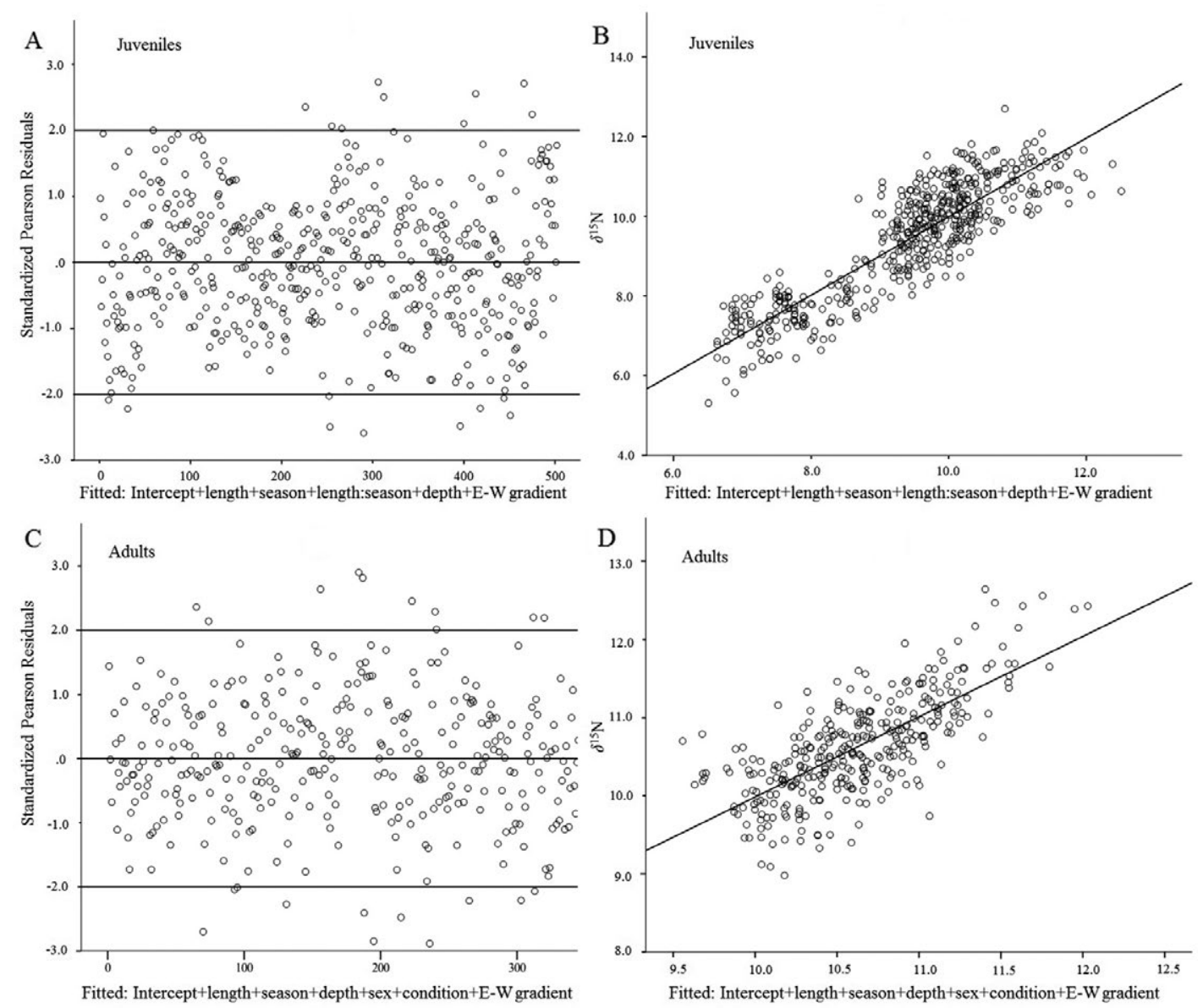

Fig. 7. - Results of the GLM with a Gamma error and an identity link for juvenile (A, B) and adult (C, D) hakes: plots of the residuals and the fitted values versus $\delta^{15} \mathrm{~N}$.

ability (22\%), while season remained important (13\%) and was followed by depth (7\%), sex $(6 \%)$, condition (2\%) and E-W gradient (1\%).

Juvenile and adult final models explained $77 \%$ and $51 \%$ of the total deviance, respectively. The diagnostic plots were satisfactory (Fig. 7A-D). Note that Figure $7 \mathrm{~B}$ tends to show a lower number of data in the range of 8.0-10\%o, which actually corresponds to a low sampling of individuals from 20 to $24 \mathrm{~cm}$ in comparison with the other size classes.

Both sexes exhibited a similar $\delta^{15} \mathrm{~N}$ trend with age but females had a higher $\delta^{15} \mathrm{~N}$ than males at the same age (Fig. 8A). The three smallest hake size classes (i.e. up to $24 \mathrm{~cm} \mathrm{~T}$ ) displayed a lower $\delta^{15} \mathrm{~N}$ in spring than in autumn (Fig. 8B). This partially matched the seasonal variation of euphausiids $\delta^{15} \mathrm{~N}$ used as the primary consumer baseline, with higher values in autumn. From $25 \mathrm{~cm} \mathrm{~T}$ there were no such large seasonal differences in the $\delta^{15} \mathrm{~N}$. In spring, the first two size classes showed similar $\delta^{15} \mathrm{~N}$, whereas the third size class (15-24 $\mathrm{cm} \mathrm{T}_{\mathrm{L}}$ ) displayed an intermediate $\delta^{15} \mathrm{~N}$ value between juveniles $\left(<15 \mathrm{~cm} \mathrm{~T} \mathrm{~T}_{\mathrm{L}}\right)$ and specimens larger than $24 \mathrm{~cm} \mathrm{~T}$. In autumn, $\delta^{15} \mathrm{~N}$ increased regularly between the different size classes. In the largest hakes $\left(25-75 \mathrm{~cm} \mathrm{~T}\right.$ ), the trends of $\delta^{15} \mathrm{~N}$ were similar in both seasons. Higher $\delta^{15} \mathrm{~N}$ values in hake $\geq 25 \mathrm{~cm} \mathrm{~T}_{\mathrm{L}}$ were observed on the continental shelf than on the shelf-break/slope (Fig. 8C).
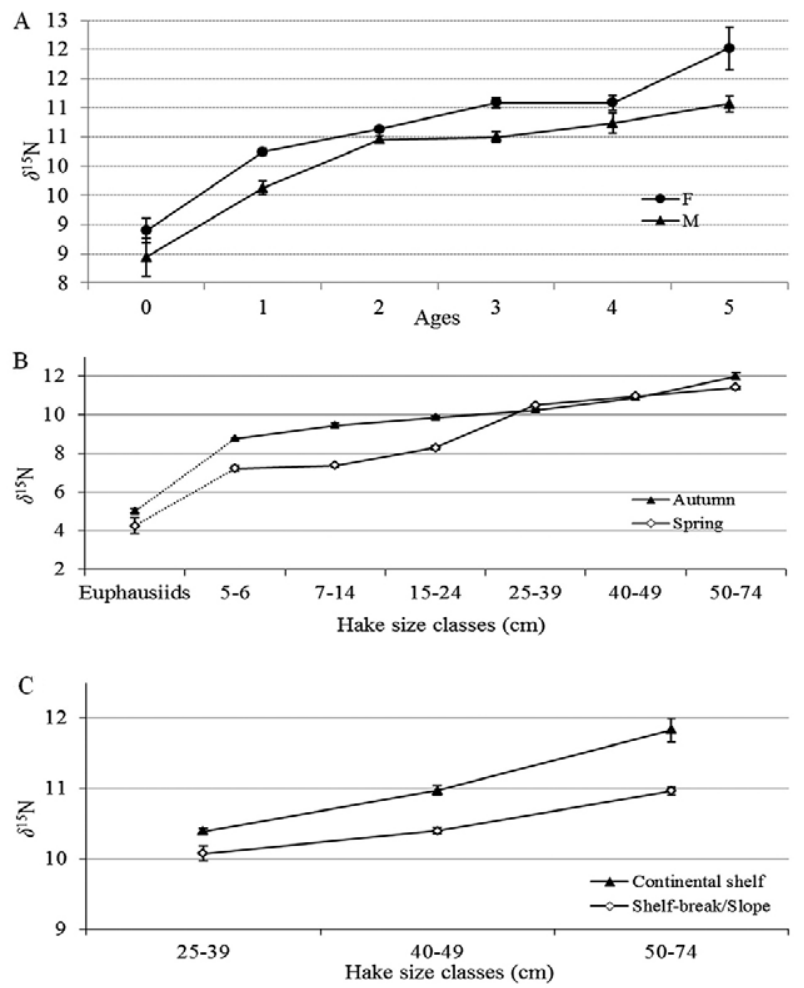

Fig. 8. - Ontogenetic $\delta^{15} \mathrm{~N}$ changes of hake with (A) sex (F, female; $\mathrm{M}$, male), (B) season $\left(\delta^{15} \mathrm{~N}\right.$ Euphausiids = baseline) and (C) depth. 


\section{DISCUSSION}

\section{Hake diet and feeding strategy}

The results of this study confirm that hake is a carnivorous predator that feeds on a variety of benthic, demersal and pelagic prey on the continental shelf and slope. Suprabenthic crustaceans and pelagic fish, i.e. sardine, anchovy and small blue whiting, were the main components of the diet and cephalopods were of minor importance. Diet changes with increasing body length from crustacean to piscivorous regimes, as previously described in the GoL (Bozzano et al. 1997, Ferraton et al. 2007) and in different hake populations world-wide (e.g. Papaconstantinou and Caragitsou 1987, Payne et al. 1987, Du Buit 1996). The shift occurred progressively between 7 and $14 \mathrm{~cm}$, reaching the piscivorous regime at $15 \mathrm{~cm} \mathrm{~T} \mathrm{~T}_{\mathrm{L}}$ before the end of the first year of life (Mellon-Duval et al. 2010). The main difference between regions is related to the dominant pelagic fish preyed on by hake: herring in the Pacific (Tanasichuk et al. 1991), anchovy and pilchard in South Africa (Pillar and Wilkinson 1995), horse mackerel and anchovy in the northern Bay of Biscay (Guichet 1995), and blue whiting and horse mackerel in the Cantabrian Sea (Velasco and Olaso 1998).

Cannibalism has been commonly observed in hake populations (Guichet 1995, Garrison and Link 2000, Cartes et al. 2004). It also occurred in the GoL, mostly on the shelf-break but at low levels $(<5 \%)$, confirming previous findings by Bozzano et al. (1997) and similar results in the southern Bay of Biscay and Portuguese coasts (Velasco and Olaso 1998, Cabral and Murta 2002). This contrasts with the central Tyrrhenian Sea, the northern Bay of Biscay and the Celtic Sea, where cannibalism can exceed 15\% (Mahe et al. 2007, Carpentieri et al. 2005). The low level of cannibalism in the GoL could be related to the weak overlap of small and large hakes, which mainly occurred during the reproductive period on the shelf-break.

Year-to-year (like seasonal) variations in diet were of low magnitude, except for the types of suprabenthic crustaceans preyed on by the smallest hake $(5-6 \mathrm{~cm})$. Amphipods were dominant in 2004 while mysids and shrimps were dominant in 2005. Similar variations were observed with a dominance of euphausiids and mysids in 2002 and of shrimps and amphipods in 2003 (Ferraton et al. 2007).

The present study confirms that hake is an opportunistic feeder, as already demonstrated (Bozzano et al. 1997, Hidalgo et al. 2008), but also shows that the length and the diversity of prey vary with hake size, probably as a result of different spatial distributions and/or foraging migration. Bozzano et al. (2005) pointed out that $2.5-4.5 \mathrm{~cm} \mathrm{~T}$ hake have not yet moved to the bottom and the 5-6 cm group represents the first recruits that settle. At this stage, juvenile hake has low mobility (Recasens et al. 1998, Arneri and Morales-Nin 2000) and our results indicate that their diet is restricted by mean prey size $<1 \mathrm{~cm} T_{L}$ and low prey diversity. The maximum prey diversity observed in the following hake size-group $(7-14 \mathrm{~cm})$ is likely to be linked to the mixed diet of crustaceans and fish and to the increasing mean length of prey to $2.6 \mathrm{~cm} \mathrm{~T}$. This wider spectrum of prey leads us to postulate that foraging migrations could start at this size class, as corresponds to previous findings in the Tyrrhenian Sea (Bartolino et al. 2008). Increasing mobility is related to the development of sensory organs allowing hake to undertake vertical nocturnal migration in water columns in response to similar movement of their prey (Bozzano et al. 2005, Mas-Riera 1991, Lombarte and Popper 2004). The decrease in diversity and the increase in the range of prey size in the diet of the three following hake size classes, from 15 to $49 \mathrm{~cm}$, is probably the result of a restrictive piscivorous regime and could suggest more mobility in the water column to catch larger fish prey.

\section{Foodweb structure}

The $\delta^{13} \mathrm{C}$ values of different size classes exhibit little variation, indicating that the hake trophic web in the GoL is based mainly on a marine phytoplankton source (and not on a Rhône river discharge-related foodweb). By contrast, $\delta^{15} \mathrm{~N}$ values changed with body size and season for both juvenile and adult hake. Size and season interaction influenced $\delta^{15} \mathrm{~N}$ in juveniles, and depth and sex also affect $\delta^{15} \mathrm{~N}$ in adults. Because small crustaceans, mainly eaten by the smallest hake, were pooled to obtain enough material for analysis, the detail of isotopic results concerning this hake size may not be very fine.

The $\delta^{15} \mathrm{~N}$ variations in a consumer can be related to changes in $\delta^{15} \mathrm{~N}$ of the baseline or changes in its diet or growth (Olive et al. 2003, Trueman et al. 2005, Sweeting et al. 2007). In the present study, ontogenetic shift in the composition and size of the prey probably explains the bulk of variations in $\delta^{15} \mathrm{~N}$ observed. Because our work is based on only two sampling periods, it is not possible to determine a direct relationship between the composition of the diet and the isotopic signature. There is indeed a time lag between the ingestion of prey and its incorporation in the tissue of the predator, and a minimum of 4 to 6 sampling periods would have been necessary. Nonetheless, the increase of $\delta^{15} \mathrm{~N}$ with body length is commonly observed in many predatory fish species (Overman and Parrish 2001, Badalamenti et al. 2002, Jennings et al. 2002), including hake (Le Loc'h and Hily 2005). In our dataset, crustaceans had a lower $\delta^{15} \mathrm{~N}$ than fish, while large blue whiting, large demersal and benthic fish had a higher $\delta^{15} \mathrm{~N}$ than the main fish prey: sardine, anchovy and small blue whiting. Most fish prey, except sardine, increased in $\delta^{15} \mathrm{~N}$ with body length.

The differences observed between spring and autumn in the $\delta^{15} \mathrm{~N}$ baseline (euphausiids) may partially explain the $\delta^{15} \mathrm{~N}$ differences observed in juvenile hakes. A lower growth rate leads to lower consumption and higher excretion of nitrogen compounds, resulting in a ${ }^{15} \mathrm{~N}$ increase in a consumer (Olive et al. 2003, Trueman et al. 2005, Sweeting et al. 2007). Morales-Nin and Moranta (2004) showed that the growth rate of juvenile hakes is lower in autumn than in spring. This finding suggests that growth could be a contributory 
factor in explaining the seasonal effect on $\delta^{15} \mathrm{~N}$ observed in juvenile hake. An increase of $\delta^{15} \mathrm{~N}$ inversely with depth was observed in hake $\geq 25 \mathrm{~cm}$ in the GoL a finding which is consistent with the work of Sherwood and Rose (2005). Influence of sex on $\delta^{15} \mathrm{~N}$ could be due to an indirect effect of growth dimorphism, male eating smaller prey sizes than females of the same age (lower $\delta^{15} \mathrm{~N}$ for males).

\section{Stock status considerations with regard to diet}

Hake and its main pelagic prey, except blue whiting, are important fishery resources in the GoL. Sardine and anchovy dominated on the continental shelf and more generally in the northwestern Mediterranean (Palomera et al. 2007), while blue whiting dominated offshore from the shelf-break. All the pelagic fish make up $40 \%$ to $80 \%$ of hake diet in the GoL, indicating their key trophic role. Since the late 2000s, the pelagic ecosystem of the GoL has shifted to a different regime, characterized by a low biomass of anchovy and sardine related to a slowdown in growth and a bad body condition (Van Beveren et al. 2014, Brosset et al. 2015). Therefore, the population fluctuations and the general "state of health" of these two species may adversely affect the diet, body condition and reproduction of their predators, and consequently reinforce the decline of hake, a species that is already severely overexploited (Jadaud et al. 2014).

Because of growth dimorphism observed in hake of the GoL (males are indeed significantly smaller than females from 2 to 3 years old, Mellon-Duval et al. 2010), males feed longer than females on smaller prey (i.e. sardine, anchovy), which they find in abundance on the continental shelf. For this reason, we hypothesize that the long and intensive exploitation on the continental shelf by trawlers, which led to the reduction of the abundance of large individuals $(80 \%$ of hake total catch in weight and $>97 \%$ in number composed of specimens $\leq 38 \mathrm{~cm}$ $\mathrm{T}_{L}$, Jadaud et al. 2014) could affect males and females differently. An increase in the mortality of males could then explain the unbalanced sex ratio observed $(80 \% \mathrm{fe}-$ male against $20 \%$ male at $38 \mathrm{~cm} \mathrm{~T}_{\mathrm{L}}$, Jadaud et al. 2014) in the hake population of the GoL.

\section{ACKNOWLEDGEMENTS}

We are grateful to all participants in the Merlumed Programme (X. Bodiguel, C. Carries, S. Charmasson, I. Cheret, F. Ferraton, T. Geoffroy, A. Guillou, C. SalenPicard and others). Determination of suprabenthos was carried out by J.C. Sorbe and F. Ferraton. Many thanks are expressed to the crew of the RV L'Europe and to the crew of the RV Tethys for their most valuable help during the MERMED, TECPEC and RESOMER surveys. We thank the two anonymous reviewers and the Editorial Board (P. Sartor) for their careful review of the manuscript and their excellent suggestions, J. Heuston for the revision of the English language and B. Guijarro for the Spanish translation. This study was funded by the IFREMER-MEDICIS, National Research Agency (ANR) and PNEC-CNRS programmes.

\section{REFERENCES}

Anonymous. 2013. International bottom trawl survey in the Mediterranean, MEDITS-Handbook, Version n. 7, 2013, MEDITS Working Group, 120 pp.

Arneri A., Morales-Nin B. 2000. Aspects of the early life history of European hake from the central Adriatic. J. Fish Biol. 56: 1368-1380. https://doi.org/10.1111/j.1095-8649.2000.tb02149.x

Badalamenti F., D’Anna G., Pinnegar J.K., et al. 2002. Size-related trophodynamic changes in three target fish species recovering from intensive trawling. Mar. Biol. 141: 561-570. https://doi.org/10.1007/s00227-002-0844-3

Bartolino V., Ottavi A., Colloca F., et al. 2008. Bathymetric preferences of juvenile European hake (Merluccius merluccius). ICES J. Mar. Sci. 65: 963-969. https://doi.org/10.1093/icesjms/fsn079

Bozzano A., Recasens L., Sartor P. 1997. Diet of the European hake Merluccius merluccius (Pisces: Merluciidae) in the Western Mediterranean (Gulf of Lions). Sci. Mar. 61: 1-8.

Bozzano A., Sardà F., Ríos J. 2005. Vertical distribution and feeding patterns of the juvenile European hake, Merluccius merluccius in the NW Mediterranean. Fish. Res. 73: 29-36. https://doi.org/10.1016/j.fishres.2005.01.006

Brosset P., Ménard F., Fromentin J.-M., et al. 2015. Influence of environmental variability and age on the body condition of small pelagic fish in the Gulf of Lions. Mar. Ecol. Prog. Ser. 529: 219-231. https://doi.org/10.3354/meps 11275

Cabana G., Rasmussen J.B. 1994. Modelling food chain structure and contaminant bioaccumulation using stable nitrogen isotopes. Nature 372: 255-257. https://doi.org/10.1038/372255a0

Cabral H.N., Murta A.G. 2002. The diet of blue whiting, hake, horse mackerel and mackerel off Portugal. J. Appl. Ichthyol. 18: 14-23. https://doi.org/10.1046/j.1439-0426.2002.00297.x

Carpentieri P., Colloca F., Cardinale M., et al. 2005. Feeding habits of European hake (Merluccius merluccius) in the central Mediterranean Sea. Fish. Bull. 103: 411-416.

Cartes J.E., Rey J., Lloris D., et al. 2004. Influence of environmental variables on the feeding and diet of European hake (Merluccius merluccius) on the Mediterranean coasts. J. Mar. Biol. Assoc. U.K. 84: 831-835. https://doi.org/10.1017/S0025315404010021h

DeNiro M.J., Epstein S. 1978. Influence of diet on the distribution of carbon isotopes in animals. Geochim. Cosmochim. Acta 42: 495-506. https://doi.org/10.1016/0016-7037(78)90199-0

Du Buit M.H. 1996. Diet of hake (Merluccius merluccius) in the Celtic Sea. Fish. Res. 28: 381-394. https://doi.org/10.1016/S0165-7836(96)00516-4

Ferraton F., Harmelin-Vivien M., Mellon-Duval C., et al. 2007. Spatio-temporal variation in diet may affect condition and abundance of juvenile European hake in the Gulf of Lions (NW Mediterranean). Mar. Ecol. Prog. Ser. 337: 197-208. https://doi.org/10.3354/meps337197

Froese R. 2006. Cube law, condition factor and weight-length relationships: history, meta-analysis and recommendations. J. Appl. Ichthyol. 22: 241-253. https://doi.org/10.1111/j.1439-0426.2006.00805.x

Garrison L.P., Link J.S. 2000. Diets of five hake species in the northeast United States continental shelf ecosystem. Mar. Ecol. Prog. Ser. 204: 243-255. https://doi.org/10.3354/meps204243

Guichet R. 1995. The diet of European hake (Merluccius merluccius) in the northern part of the Bay of Biscay. ICES J. Mar. Sci. 52: 21-31 https://doi.org/10.1016/1054-3139(95)80012-3

Harmelin-Vivien M., Loizeau V., Mellon-Duval C., et al. 2008. Comparison of $\mathrm{C}$ and $\mathrm{N}$ stable isotope ratios between surface particulate organic matter and microphytoplankton in the Gulf of Lions (NW Mediterranean). Cont. Shelf Res. 28: 1911-1919. https://doi.org/10.1016/j.csr.2008.03.002

Hidalgo M., Massuti E., Moranta J., et al. 2008. Seasonal and short spatial patterns in European hake (Merluccius merluccius L.) recruitment process at the Balearic Islands (western Mediterranean): the role of environment on distribution and condition. J. Mar. Syst. 71: 367-384. https://doi.org/10.1016/j.jmarsys.2007.03.005 
Hyslop E.J. 1980. Stomach content analysis-a review of methods and their application. J. Fish Biol. 17: 411-429. https://doi.org/10.1111/j.1095-8649.1980.tb02775.x

Jadaud A., Guijarro B., Rouyer T., et al. 2014. Working Group on Stock Assessment on Demersal Species. Assessment of Hake (Merluccius merluccius) in GSA 07 (Gulf of Lions). SAC, GFCM Sub Committee on Stock Assessment, Montenegro, Bar, 28 January-1st February 2014.

Jennings S., Pinnegar J.K., Polunin N.V.C., et al. 2002. Linking size-based and trophic analyses of benthic community structure. Mar. Ecol. Prog. Ser. 226: 77-85 https://doi.org/10.3354/meps226077

Le Cren E.D. 1951. The length-weight relationship and seasonal cycle in gonad weight and condition in the perch (Perca fluviatilis). J. Anim. Ecol. 20: 201-219. https://doi.org/10.2307/1540

Le Loc'h F., Hily C. 2005. Stable carbon and nitrogen isotope analysis of Nephrops norvegicus/Merluccius merluccius fishing grounds in the Bay of Biscay (Northeast Atlantic). Can. J. Fish. Aquat. Sci. 62: 123-132 https://doi.org/10.1139/f04-242

Lombarte A., Popper A.N. 2004. Quantitative changes in the otolithic organs of the inner ear during the settlement period in European hake Merluccius merluccius. Mar. Ecol. Prog. Ser. 267: $233-240$ https://doi.org/10.3354/meps267233

Lorrain A., Savoye N., Chauvaud L., et al. 2003. Decarbonation and preservation method for the analyses of organic $\mathrm{C}$ and $\mathrm{N}$ contents and stable isotope ratios of low-carbonated suspended particulate material. Anal. Chim. Acta 491: 125-133. https://doi.org/10.1016/S0003-2670(03)00815-8

Mahe K., Amara R., Bryckaert T., et al. 2007. Ontogenetic and spatial variation in the diet of hake (Merluccius merluccius) in the Bay of Biscay and the Celtic Sea. ICES J. Mar. Sci. 64: 1210-1219. https://doi.org/10.1093/icesims/fsm100

Mas-Riera J. 1991. Changes during growth in the retinal structure of three hake species, Merluccius spp. (Teleostei: Gadiformes), in relation to their depth distribution. J. Exp. Mar. Biol. Ecol. 152: $91-104$ https://doi.org/10.1016/0022-0981(91)90137-L

Mellon-Duval C., de Pontual H., Metral L., et al. 2010. Growth of European hake (Merluccius merluccius) in the Gulf of Lions based on conventional tagging. ICES J. Mar. Sci. 67: 62-70. https://doi.org/10.1093/icesjms/fsp215

Minagawa M., Wada E. 1984. Stepwise enrichment of ${ }^{15} \mathrm{~N}$ along food chains: Further evidence and the relation between $\delta^{15} \mathrm{~N}$ and animal age. Geochim. Cosmochim. Acta 48: 1135-1140 https://doi.org/10.1016/0016-7037(84)90204-7

Morales-Nin B., Moranta J. 2004. Recruitment and post-settlement growth of juvenile Merluccius merluccius on the western Mediterranean shelf. Sci. Mar. 63: 399-409. https://doi.org/10.3989/scimar.2004.68n3399

Olive P.J.W., Pinnegar J.K., Polunin N.V.C., et al. 2003. Isotope trophic-step fractionation: a dynamic equilibrium model. J. Anim. Ecol. 72: 608-617. https://doi.org/10.1046/j.1365-2656.2003.00730.x

Overman N.C., Parrish D.L. 2001. Stable isotope composition of walleye: ${ }^{15} \mathrm{~N}$ accumulation with age and area-specific differences in $\delta^{13}$ C. Can. J. Fish. Aquat. Sci. 58: 1253-1260. https://doi.org/10.1139/f01-072

Palomera I., Olivar M.P., Salat J., et al. 2007. Small pelagic fish in the NW Mediterranean Sea: an ecological review. Prog. Oceanogr. 74: 377-396 https://doi.org/10.1016/j.pocean.2007.04.012

Papaconstantinou C., Caragitsou E. 1987. The food of hake (Merluccius merluccius) in Greek Seas. Vie Milieu 37: 77-83.

Payne A.I.L., Rose B., Leslie R.W. 1987. Feeding of Hake and a 1st attempt at determining their trophic role in the South-African West-Coast Marine-Environment. Afr. J. Mar. Sci. 5: 471-501. https://doi.org/10.2989/025776187784522667
Pillar S.C., Wilkinson I.S. 1995. The diet of Cape hake Merluccius capensis on the South Coast of South-Africa. Afric. J. Mar. Sci. 15: 225-239. https://doi.org/10.2989/02577619509504845

Post D.M. 2002. Using stable isotopes to estimate trophic position: models, methods, and assumptions. Ecology 83: 703-718. https://doi.org/10.1890/0012-9658(2002)083[0703:USITET]2. $0 . \mathrm{CO} ; 2$

Post D.M., Layman C.A., Arrington D.A., et al. 2007. Getting to the fat of the matter: models, methods and assumptions for dealing with lipids in stable isotope analyses. Oecologia 152: 179-189. https://doi.org/10.1007/s00442-006-0630-x

R Development Core Team. 2009. R: a language and environment for statistical computing. R Foundation for statistical computing, Vienna, Austria, ISBN 3-900051-07-0, http://www.R-project.org

Recasens L., Lombarte A., Morales-Nin B., et al. 1998. Spatiotemporal variations in the population structure of the European hake in the NW Mediterranean. J. Fish Biol. 53: 387-401. https://doi.org/10.1111/j.1095-8649.1998.tb00988.x

Scrimgeour C., Robinson D. 2003. Stable isotope analyses and applications. In: Smith K.A., Cresser M.S., Dekker M. (eds), New York, pp 381-431.

Sherwood G.D., Rose A. 2005. Stable isotope analysis of some representative fish and invertebrates of the Newfoundland and Labrador continental shelf food web. Est. Coast. Shelf Sci. 63. 537-549 https://doi.org/10.1016/j.ecss.2004.12.010

SPSS. 2008. SPSS Statistics 17.0, Rel. 17.0.7, 23 August 2008. SPSS Inc., Chicago.

Sorbe J.C. 1999. Deep-sea macrofaunal assemblages within the Benthic Boundary Layer of the Cap Ferret Canyon (Bay of Biscay, NE Atlantic Ocean). Deep-Sea Research, Part II-Topical Stud. Oceanogr. 46: 2309-2329. https://doi.org/10.1016/S0967-0645(99)00064-8

Sweeting C.J., Barry J., Barnes C., et al. 2007. Effects of body size and environment on diet-tissue D15N fractionation in fishes. J. Exp. Mar. Biol. Ecol. 340: 1-10. https://doi.org/10.1016/j.jembe.2006.07.023

Tanasichuk R.W., Ware D.M., Shaw W., et al. 1991. Variations in diet, daily ration, and feeding periodicity of pacific Hake (Merluccius productus) and Spiny Dogfish (Squalus acanthias) off the lower West-Coast of Vancouver Island. Can. J. Fish. Aquat. Sci. 48: 2118-2128 https://doi.org/10.1139/f91-251

Trueman C.N., Mc Gill R.A.R., Guyard P.H. 2005. The effect of growth rate on tissue diet isotopic spacing in rapidly growing animals. An experimental study with Atlantic salmon (Salmo salar). Rapid Commun. Mass Spectrom. 19: 3239-3247. https://doi.org/10.1002/rcm.2199

Tyler A.V. 1972. Food resource division among northern marine demersal fishes. J. Fish. Res. Board Can. 29: 997-1003. https://doi.org/10.1139/f72-144

Vander Zanden M.J., Cabana G., Rasmussen J.B. 1997. Comparing trophic position of freshwater fish calculated using stable nitrogen isotope ratios $(\delta 15 \mathrm{~N})$ and literature dietary data. Can. J. Fish. Aquat. Sci. 54: 1142-1158. https://doi.org/10.1139/f97-016

Van Beveren E., Bonhommeau S., Fromentin J-M., et al. 2014. Rapid changes in growth, condition, size and age of small pelagic fish in the Mediterranean. Mar. Biol. 161: 1809-1822. https://doi.org/10.1007/s00227-014-2463-1

Velasco F., Olaso I. 1998. European hake Merluccius merluccius (L., 1758) feeding in the Cantabrian Sea: seasonal, bathymetric and length variations. Fish. Res. 38: 33-44. https://doi.org/10.1016/S0165-7836(98)00111-8

Venables W.N., Dichmont C.M. 2004. GLMs, GAMs and GLMMs: an overview of theory for applications in fisheries research. Fish. Res. 70: 319-337. https://doi.org/10.1016/j.fishres.2004.08.011 